IRA-International Journal of Management \& Social Sciences

ISSN 2455-2267; Vol.08, Issue 01 (July 2017)

Pg. no. 118-123

Institute of Research Advances

http://research-advances.org/index.php/RAJMSS

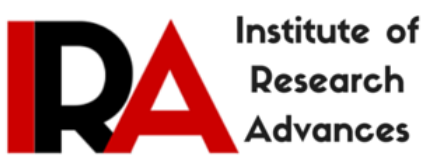

\title{
Art as Narrative: Recounting Trauma through Literature
}

\author{
Sadiya Abubakar
}

Research Scholar, Department of English

Lovely Professional University, Punjab, India.

Type of Review: Peer Reviewed.

DOI: http://dx.doi.org/10.21013/jmss.v8.n1.p13

How to cite this paper:
Abubakar, S. (2017). Art as Narrative: Recounting Trauma through Literature. IRA-International
$\begin{aligned} & \text { Journal of Management \& Social Sciences (ISSN } \\ & \text { doi:http://dx.doi.org/10.21013/jmss.v8.n1.p13 }\end{aligned}$
doi:http://dx.doi.org/10.21013/jmss.v8.n1.p13

(c) Institute of Research Advances.

(cc) EY-NC

This work is licensed under a Creative Commons Attribution-Non Commercial 4.0 International License subject to proper citation to the publication source of the work.

Disclaimer: The scholarly papers as reviewed and published by the Institute of Research Advances (IRA) are the views and opinions of their respective authors and are not the views or opinions of the IRA. The IRA disclaims of any harm or loss caused due to the published content to any party.

Institute of Research Advances is an institutional publisher member of Publishers Inter Linking Association Inc. (PILA-CrossRef), USA. The institute is an institutional signatory to the Budapest Open Access Initiative, Hungary advocating the open access of scientific and scholarly knowledge. The Institute is a registered content provider under Open Access Initiative Protocol for Metadata Harvesting (OAI-PMH).

The journal is indexed \& included in WorldCat Discovery Service (USA), CrossRef Metadata Search (USA), WorldCat (USA), OCLC (USA), Open J-Gate (India), EZB (Germany) Scilit (Switzerland), Airiti (China), Bielefeld Academic Search Engine (BASE) of Bielefeld University, Germany, PKP Index of Simon Fraser University, Canada. 


\begin{abstract}
In literature, all human phenomena are reflected by literary works and related to the world through simple artistic mediums. It is no doubt that trauma exists as part of human challenges since the start of human history. However, the concept of trauma has been theorized in the fields of sciences and social sciences since ages i.e. Medicine, Psychology etc. only soon did it gain credence and was theorized in the stream of literature by some competent, scholarly and capable professors of comparative literature at Emory University; Cathy Caruth and Shoshana Felman. As the world evolves from one age to another, so does literature, binding history and culture of a place and people efficiently. Trauma has as well been one way or another, prevalent in all forms of literature. It surfaces as the shady part of all narratives that tell of a history, memoir, agonies and sorrows of the writer or about the subjects (characters) created.

This paper explores the origins of trauma theory and deciphers its essential role in literature. It argues that trauma in literature is a must-read because, the theoretical multiplicity that allows for an appreciative comprehension of trauma's flexible representations include (and also move beyond) the idea of trauma as neurotic, appalling, horrifying, terrifying and the pleasure of telling and witnessing a traumatic event which is, of course, literature.
\end{abstract}

Key words: Art as Narrative; Recounting History; Trauma Theory; World Literature

\title{
"In all forms of art, part of you is in the trauma, and part of you is a step away from it."
}

$\sim$ Maya Angleou

The word trauma is said to have originated from the Latin word 'Trauma' which is derived from the Greek word 'Traumatikos' which means a serious wound to the body. Trauma is referred to as any emotional wound leading to psychological injury or an event that causes great distress. According to American Psychological Association, trauma is referred to as an emotional response to a terrible event. Alameda County Trauma Informed Care, a trauma and mental health care organization in Alameda County, California, refers to trauma from a psychological perspective to describe experiences that are emotionally painful and distressing and that overwhelms an individual's capacity to cope. Dejonghe, a psychologist and sociologist at the California Polytechnic University, USA, in a symposium on 'Women Survivors of Intimate Partner Violence and Post-traumatic Stress Disorder: Prediction and Prevention', describes the concept of trauma as: "experiencing or witnessing an event involving threat or fear or physical integrity that results in feelings of fear, helplessness, or horror" (Dejonghe 294).

Trauma is said to have more psychological effects than physical, the effects are mentally threatening and can lead to a mental and even physical breakdown if not taken care of. Sandra L. Bloom, a psychiatrist who specializes in the treatment of psychological trauma, quoted Lenore Terr, a child psychiatrist in her work Trauma Theory Abbreviated, saying,and "Psychic trauma occurs when a sudden unexpected overwhelming intense emotional blow or series of blows assaults the person from outside. Traumatic events are external, but they quickly become incorporated into the mind" (Bloom 2).

In modern times, trauma theory has gained an independent scope for itself; it is studied as a theory of its own. Although, its origins can still be traced back to Freud's psycho analysis, Rick Curnow Adelaide; a psychoanalyst and training analyst at Australian Psychoanalytical Society, in a public lecture on 'Trauma: A Psychoanalytic Perspective', maintains that the theory of trauma was said to have sprung out of Freud's Psychoanalysis where he (Freud) believes that "all neurosis was a result of previous traumatic experience" (Rick 2).The term "Post-Traumatic Stress Disorder" (PTSD) is a concept which is very central to trauma theory; it was coined from Freud's "traumatic neurosis" by the American Psychiatric Association in 1980. PSTD is one of the world's deadliest illnesses; it is responsible for the deaths of many and has been the reason why many trauma centers are functionally operating in the West today. In the war infested parts of the world, victims of terror do not suffer terror attack as much as they suffer PSTD that becomes persistent afterwards.

However, in modern theory, trauma theory is considered an infant, a new born which is said to have been first used by Cathy Caruthin her workUnclaimed Experience (1996). According to Khan Touseef Osman, in his research article on "Trauma Theory and Its Implications in Humanities and Social Sciences", he confirms that: 
The term "trauma theory" first appears in Cathy Caruth's Unclaimed Experience. The theory, arguably, stems from her insightful interpretation and elaboration of Freud's deliberations on traumatic experiences in Beyond the Pleasure Principle and Moses and Monotheism. (Osman 1)

Elissa Marder, a professor of French and comparative literature at Emory University, in her essay Trauma and Literary Studies: Some "Enabling Questions" also observes that' In the late $20^{\text {th }}$ century, Cathy Caruth, a distinguished research professor of comparative literature and English is considered as one of the leading pioneers of trauma theory, she theorized the concept of trauma in the light of literature, that, literary texts are means through which the nature of trauma is revealed by its witnesses. She argues that literature enables us to bear witness to events that can't be absolutely known and introduces us to experiences that might have otherwise stayed unspoken and unheard. Caruth powerfully and convincingly shows that despite the fact that certain kinds of events can't be completely understood, these events consequently become significant in diverse ways by being expressed to others and perceived by them. (Elissa 3)

Elissa further explored the nature of traumatic events and its response by citing the creative work of Shoshana Felman, also a professor of comparative Literature at Emory who have creatively worked on the issues of trauma, literature and psychoanalysis.

“The focus of Shoshana Felman's first invaluable contribution to trauma studies-her 1992 book Testimony: Crises of Witnessing in Literature, Psychoanalysis, and History - centers on what she calls "testimony"According to Felman (and her co-author Dori Laub), testimony (here understood as the act of bearing witness to traumatic events) is a necessary and vital response to the ongoing consequences of traumatic history" (Elissa 3).

It is generally believed that trauma theory is an amalgam of psychological studies with that of humanities. In literature especially, the theory is imbibed in the study of the multiple dimension of characters' psyche. Susannah Radstone et al opine that: "Trauma theory denotes a vibrant, interdisciplinary area of Western scholarship developed since the 1980s through cross-fertilization between psychology and the humanities" (Radstone 1). In literary studies, some narratives with traumatic themes, moods and tones are eminent in keeping alive a psychological wound alongside telling others the pains in a traumatic experience. Another noteworthy aim of trauma narratives is to restructure cultural memory through individual perspectives, taking on testimonial traits to avert and bear witness against such repetitious horrors. (Laurie 5).

In literature, all human phenomena are reflected by literary works and related to the world through simple artistic mediums. It is of no doubt that trauma exists as part of human challenges since the start of human history. However, the concept of trauma has been theorized in the field of sciences since ages i.e Medicine, Psychology etc. but only soon did it gain credence and was theorized in the stream of literature by some able professors of comparative literature at Emory University. Cathy Caruth and Shushana Felman, they have enormously worked this out indeed. As the world evolves from one age to another, so does literature, binding history and culture of a place and people lucratively. Trauma has as well being one way or another, prevalent in all forms of literature. It surfaces as the shady part of all narratives that tell of a history, memoir, agonies and sorrows of the writer or about the subjects (characters) written.

The trauma novel demonstrates how a traumatic event disrupts attachments between self and others by challenging fundamental assumptions about moral laws and social relationships that are themselves connected to specific environments. Novels represent this disruption between the self and others by carefully describing the place of trauma because the physical environment offers the opportunity to examine both the personal and cultural histories imbedded in landscapes that define the character's identity and the meaning of the traumatic experience. The primacy of place in the representations of trauma anchors the individual experience within a larger cultural context, and, in fact, organizes the memory and meaning of trauma. (Balaev 1).

From the beginning of time, trauma, which can be experienced in various forms, is ascribed to the expulsion of Adam and Eve from heaven (The Garden of Eden) to earth. According to Quranic and Biblical narration of the evolution of man, their shocking and surprising heartbreak left them traumatized. Adam and Eve lost the paradise after their disobedience to God; they were thrown out of heaven for eating from the forbidden tree. Only then did they realize that they were naked, which is a sign of another fall from purity. Thus, they both encountered physical and psychological trauma as Adam is said to have wept for seventy years. John Milton's Paradise Lost is a near example of such kind of traumatic experience in narrative literature. 
The historic holocaust has till today left a mark in the human history. Since literature serves as a means of historical documentation and transmission, Anne Frank's The Dairy of a young Girl (1947) is the dairy entries of a teenager which reveals the horrors of holocaust. This autobiography is about two Jewish families who fled from Germany to Amsterdam and are in hiding from the Nazi Germans. The horrific experiences of the oppressed and the sympathetic situation they find themselves result to their exposure to traumatic experiences. Anne, the protagonist is subjected to the feeling of loneliness, isolation and fear. With thoughts and wondering of the reason why the Jews are persecuted, she grows up with a staunch solidarity among the aggrieved of the brutal circumstances of the Holocaust without making it till the end. Other books of the same plight are: Elie Wiesel's Night (1958), Charles Weinblatt's Jacobs Courage: A Holocaust Love story etc.

Similarly, the growth and development of trauma continued through series of ruins and destructions that occurred in human history. During and after the world wars, victims of war suffered various forms of psychological and physical trauma leading to creation and or establishment of multiple rehabilitation centers as well as Trauma care centers. This has enormously been illustrated in the literary works of most twentieth century fiction writers. The mission of war mongers has been accomplished; destruction of minds, lives and properties made. War has ended but the effect of war still remains even much longer than the war itself.

Virginia Woolf rightfully portrayed this psychological effect of war in her text Mrs. Dalloway through the character of Septimus Waren Smith, a war Veteran who lost his very close friend to the war. Devastated by the experiences of a war front, Septimus becomes mentally traumatized. He blames himself for every tragic event that happens thereafter, hallucinates and secludes from the real world. At long run, he resorts to committing suicide. This is how veterans and others involved with war one way or the other are traumatized resulting from their punitive and harsh experiences.

With the passage of time, the growth and expansion of trauma extended in numerous forms, varying from communal, religious, regional and colonial reasons. The extension of European trade system brought many places like the whole continent of Africa, some parts of Asia and Middle-East under European empires. Thus, Post-colonial writers are mostly engulfed with the horrible effects and experiences of colonialism. The colonialized are mostly victims of oppression, subjugations and depression thereby showing the impacts of trauma.

Chinua Achebe's Things fall apart (1958) is a colonial text set in the eastern part of Nigeria. The European invasions consequently disturbed and disrupted the seemingly peaceful villages of eastern Nigeria traumatizing both the natives and the readers too. Okonkwo, the protagonist, is a brave and agile man, the tragic hero who commits suicide due to his inability to accept the British into his village and psyche. He became mentally devastated when he released that his village members are not willing to fight the invaders. Thus, he becomes depressed and overly affected psychologically. Suicide becomes his available escape route because he can't stand the trauma.

'Traumatic experience can produce a sometimes indelible effect on the human psyche that can change the nature of an individual's memory self-recognition and relational life' (Laurie 22).

Furthermore, works like Frantz Fanon's Black Skin, White Masks (1952),AyiKwei Armah's Fragments (1970), NgugiWa' Thiongo's Decolonizing the Minds (1986), Salman Rushdie's Midnight's Children (1981), Arundhati Roy's The God of Small Things (1997), Chimamanda Adichie's Half of a Yellow Sun (2006), Christopher Abani's Grace Land(2004) etc. are good examples of post-colonial writings depicting the traumatization of individuals due to colonial force.

The progression of human awareness and exploration in the history of man, leads to the realization of other races other than "whites" (as the Europeans put it). From then on, color became a thing of difference among humans and thus racism began to develop in the human mindset. The Europeans termed themselves 'whites' and the 'others' as red, black or brown. Racism is another root cause of trauma, which if care is not taken, can cause a lot of mental agony. It is so frustrating that its victims are excessively exposed to psychological trauma which may or may not reveal itself in their outer life.

Joe Christmas of William Faulkner's Light in August suffers the same kind of trauma. A character gets exposed to the frailties of racism right from birth when dumped at the orphanage by his maternal grandfather due to hatred for his black race. He was then moved from the white orphanage to black orphanage because of his race. Adopted by Mr. McEachern, he suffers torture and domestic violence at a young age all because of his race. Bobbie, the girl he loves also ditched him because he is partly a black. All these and many other forms of racism subjected Joe Christians to depression and internal conflict which detached him from himself and the society at large. His situation is similar to that of Sophia in Alice Walker's The Color Purple. Joe Christmas' trauma unfolds into the feeling of dehumanization, aggressiveness and selflessness. Thus, he 
kills and gets killed. Death becomes his escape route like other tragic heroes. Another textual example of trauma caused by racism is Harper Lee's To Kill a Mocking Bird (1960), Ralph Ellison's Invisible Man (1952) etc.

"After a traumatic event...... there may be two distinct phrases. There is an initial breakdown when the protective shield is breached by trauma and there may be a catastrophic disruption of functioning" (Rick 7)

In the recent years, terrorism has distorted the history of man. What appears to be religious act is in reality, simply born out of political manipulations. Till today, the survivors of terrorist attacks are the bearers of the pains and suffering related to shocking situation. The trauma experienced as a result of terrorism is similar to that of holocaust, wars or genocides. Thus, survivors of terrorist attacks suffered from devastation, wretchedness, loss of mood, confusion, feeling of insecurity, haunting memories, hallucinations and images etc.

"From an earlier focus on the interpersonal aspects of trauma, including child abuse and domestic violence, traumatic experiences have taken on a political and social dimension, for example, the events of 9/11, the war on terror, and combat trauma associated with recent wars in Afghanistan and Iraq". (Ringel vii)

Don DE Lillo's Falling man is a potent representation or symbol of America's 9/11 twin Towers attack and its aftermath. Keith Neudecker's victimization and disorientation results from the said terrorist attack. The vision of "a man flying himself out of one of the broken windows on the top floors of the World Trade Centre on that fateful day in 2001" remains unforgettable; an image that they can't get off their minds. Witnesses and survivors live a life but a life filled with post traumatic tensions that would take forever to get over it. Other relevant texts include Michael Cunningham's Specimen day (2005), Kushwan Singh's Train to Pakistan, InaamKachachi's The American Granddaughter, Mohsin Hamid's The Reluctant Fundamentalist (2007), Khaled Hosseni's The Kite Runner (2003) etc.

Today, the concept of trauma doesn't only involve life threatening events or emotionally painful events but also situations or day-to-day experiences or activities that can lead to mental frailties. Centuries have passed by but human situation still remains similar. An increasing rate of unfaithfulness, helplessness, fear and lack of self-control in some cases are direct repercussions of trauma. The predominant causes for traumatic feelings are experiences such as rape, domestic violence, child abuse, poverty, sexual assaults, natural calamities and disasters, disease outbreaks and pandemics, loss of loved ones, societal and religious intolerance, discontentment or desperately materialistic, chaos and violence witnessing etc.

These traumatic events, experiences and effects have aptly been symbolically portrayed by novelists globally in literary works such as: Margaret Atwood's Surfacing, Maheshwati Devi's Rudali, Buchi Emacheta's Joys of motherhood, Rajaa Alsenea's Girls of Riyadh, Hanan al-Shaykh's Only in London, Anita Desai's Cry The Peacock, Sashi Despande's That Long Silence and The Dark holds no Terrors, GirishKarnad's Nagamadala, William Faulkner's Light in August, Rupa Bajwa's The Sari Shop, Flora Nwapa's Efuru, Chimamanda Adichie's Half of a yellow sun and Purple Hibiscus among many others.

The concept of trauma theory in literature is slowly and steadily gaining a reading and research attention globally; many research works, dissertations and thesis have been done and are in the process of research till date, with respect to trauma in literary studies. Confirmatory evidence of its research achievements and developments can be seen in journals such as The Journal of Literature and Trauma Studies which methodologically focuses on the relationship between trauma and literature. Although, most academics in most third-world countries are yet to discern the trend of trauma theory in literature, it is still treated as a part of psychoanalytic criticism. Trauma in literature is a must-read because, the theoretical multiplicity that allows for an appreciative comprehension of trauma's flexible representations include (and also move beyond) the idea of trauma as neurotic, appalling, horrifying, terrifying and the pleasure of telling and witnessing a traumatic event which is, of course, literature.

\section{References}

1. Balaev, Michelle. "Trends in Literary Trauma Theory". Questia: Trusted online research. Mosaic (Winnipeg). V 41.No. 2. June 2008. Web. 23 Nov. 2016. https://www.questia.com/library/journal/1G1235281138/trends-in-literary-trauma-theory 
2. Bloom, Sandra L., and M.D. Trauma Theory Abbreviated. Department of Human Services, Victoria, Australia.N.p. 1999. Web. 01 Nov, 2015. http:// www. dhs. Vic .gov. au/data / assets / pdf_file /0005 /587966/trauma_theory_abbreviated_sandra_bloom.pdf

3. Caruth, Cathy. Unclaimed Experience trauma, Narrative and History. London: The John Hopkins University Press, 1996. Print.

4. DeJonghe E. S. et al. Women survivors of intimate partner violence and post-traumatic stress disorder: Prediction and prevention. Bioline International.N.p. Oct, 2008. Web. 30 Oct, 2015. http://www.bioline.org.br/pdf?.jp08102

5. Elissa, Marder. Trauma and Literary Studies: Some "Enabling Questions". Reading On: A Journal of Theory and Criticism.N.p. 01 Jan, 2006. Web. 01 Nov, 2015. http: // read ingon. library. emory. Edu /issue1 /articles /Marder /RO\%20-\% $202006 \%$ 20-\% 20 Marder.pdf

6. Felman, Shoshana and DoriLaub, MD. Testimony Crises of Witnessing in Literature, Psychoanalysis and History.Routledge.Newyork. 1992. Print.

7. Rick Curnow, Adelaide. A Public Lecture, Trauma: A Psychoanalytic Perspective. Adelaide Institute of Psychoanalysis. 22 March, 2007. Web. 01 Nov, 2015. http://www.aipsych.org.au/articles/aip_trauma_psychoanalytical.pdf

8. Shoshana Ringel., and Jerrold R. Brandell. Eds. Trauma Contemporary Directions in Theory, Practice, and Research. Sage Publications.Carlifonia. 2012. Web. 20 Oct, 2015. https://us.sagepub.com/sites/default/files/upm-binaries/40688_1.pdf

9. Vickroy, Laurie. Trauma and Survival in Contemporary Fiction. US: The University of Virginia Press. 2002. Print.

10. http://www.sparknotes.com/lit/annefrank/summary.html

11. http://www.oxfordbibliographies.com/view/document/obo-9780199791286/obo-97801997912860147.xml 